\title{
Service Recovery Activities and Customer Satisfaction: Mediating Role of Justice Dimensions: A Case Study of China
}

\author{
Wang XiaoRan ${ }^{1} \&$ Rozeyta Omar ${ }^{1}$ \\ ${ }^{1}$ Faculty of Management, University Technology Malaysia, Malaysia \\ Correspondence: Rozeyta Omar, Faculty of management, University Technology Malaysia, Malaysia. E-mail: \\ wangxiaoran124@gmail.com
}

Received: July 9, 2014 Accepted: July 25, 2014 Online Published: August 25, 2014

doi:10.5539/ass.v10n18p253

URL: http://dx.doi.org/10.5539/ass.v10n18p253

\begin{abstract}
Customer satisfaction and its contribution to service quality improvement, especially through effective service recovery programs, are not new to researchers. Several studies have identified the impact of service recovery activities on customer post-recovery satisfaction mostly in Western countries, and very few have examined how Asian consumers react to service recovery efforts, especial in China. It implicates that the impact of a hotel's service recovery strategies is derived from three justice dimensions. Customer perception of overall distributive justice is influenced by apology, while providing cognitive control (i.e., keeping customers informed) affects procedural justice. Finally, the manner in which service personnel treat a customer (politeness, respect, and courtesy) during the recovery process affects perceptions of interactional justice. Finally, all three forms of justice (distributive, procedural, and interactional) positively impact overall service recovery satisfaction.
\end{abstract}

Keywords: service recovery, justice dimension, customer satisfaction

\section{Introduction}

In today's ever-growing global environment, the Chinese hotel industry is competing for a greater market share and profitability by increasing customer satisfaction and loyalty (Lee, Singh, \& Chan, 2011). Numerous researchers have pointed out that customer satisfaction has become the primary goal for most hotels over the past decades. It is implied that customer satisfaction may lead to lower marketing expenditure, greater profitability, positive word-of-mouth, and even customer loyalty (Anderson, Fornell, \& Mazvancheryl, 2004). However, service failure is sometimes inevitable due to human or non-human error, unfortunately causing customer dissatisfaction (Kau \& Loh, 2006). Meanwhile, the breakdown in the relationship between customers and service providers due to service failure can contribute to a rise in customer complaints, negative word-of-mouth communication, customer dissatisfaction and defection. Luckily, service recovery offers a second chance as a valuable marketing tool for the service provider. It refers to the activities that recuperate customer satisfaction and secure the relationship between customers and service providers (Sparks \& McColl-Kennedy, 2001). Researchers utilized three justice dimensions (i.e., perceptions of distributive, interactional and procedural justice) as the main framework to fundamentally examine service recovery procedures (McColl-Kennedy \& Sparks, 2003; Michel, 2001). The intent of this study is to investigate the relationship between service recovery processes and consumer satisfaction in the hotel industry in China.

\section{Theory and Hypothesis}

\subsection{Service Recovery}

Service recovery is the process of dealing with a situation, whereby a customer has experienced service failure from a service organization. It is also defined as the proactive and reactive actions of a service provider in response to customer complaints (Gronroos, 1988), or a specific set of actions to resolve customer problems, alter negative attitudes of dissatisfies customers, and ultimately restore customer loyalty (Miller, Craighead, \& Karwan, 2000). According to Fang, Luo, and Jiang (2013), service failure severity is related to the level of customer dissatisfaction. To solve problems, service providers generally employ revitalization strategies to reduce customer dissatisfaction as well as switching rate. Proper service recovery actions from service providers may resolve customer complaints and restore customer satisfaction. Service recovery strategies include problem acknowledgment, explanations about the service failure, apologizing, employee empowerment to solve problems, 
and compensation (e.g., full or half refunds, discounts, coupons, free service upgrades, free gifts, etc.), and being respectful, polite and courteous during the service recovery process (Bitner, Booms, \& Mary, 1990; Blodgett, Hill, \& Tax, 1997; Mattila \& Patterson, 2004; Sparks \& McColl-Kennedy, 2001). While evidence for the "recovery paradox" is sparse and varied, it is generally agreed that effective service recovery can redirect dissatisfied customers to a state of satisfaction and it go a long way towards limiting the harmful impact of service failure (Boshoff, 1997; Boshoff \& Leong, 1998; Michel, 2001). Consequently, past studies have applied the Justice Theory to evaluate service recovery efforts following service failure and included distributive justice, interactional justice, and procedural justice (Patterson, Cowley, \& Prasongsukarn, 2006; Schoefer, 2010).

\subsection{The Justice Dimension}

The justice theory is the main framework utilized by numerous researchers to fundamentally examine service recovery procedures (McColl-Kennedy \& Sparks, 2003; Michel, 2001). The justice theory is extracted from the equity theory and social exchange theory and is based on social psychology where the individual customers' fairness perceptions of service recovery situations and decisions are examined (Adams, 1965). Hoffman and Kelly (2000) applied the social exchange theory to a service recovery procedure and proposed that customers weigh their sum of inputs (economics, time, energy, and psychic cost) against their sum of outputs (cash refund, apology, replacement, and manner of staff) when they evaluate service recovery efforts. Perceived justice suggests that all actions during the recovery process and outcome delivery are all critical to recovery evaluation. Accordingly, perceived justice consists of three dimensions: distributive justice, procedural justice and interactional justice (Tax \& Brown, 1998).

Distributive justice primarily concerns firms offering tangible resources to rectify and compensate for service failure, such as compensation in the form of discounts, coupons, refunds, free gifts, replacements, apologies (Blodgett et al., 1997; del Río-Lanza, Vázquez-Casielles, \& Díaz-Martín, 2009; Goodwin \& Ross, 1992; Hoffman \& Kelly, 2000; Tax \& Brown, 1998).

Procedural justice refers to five elements that organizations deal with when problems arise during service delivery, namely process control, decision control, accessibility, timing/speed and flexibility (del Río-Lanza et al., 2009; Tax \& Brown, 1998). Procedural justice also includes policies, procedures, and tools that companies use to support communication with customers and more specifically, the time taken to process complaints and to arrive at a decision (Davidow, 2003).

Interactional justice focuses on interpersonal interactions during the process of service delivery (Nikbin, Ismail, Marimuthu, \& Jalalkamali, 2010). It is further identified as having five elements: explanation/causal account, honesty, politeness, effort and empathy. In a service recovery situation, interactional justice would refer to the manner in which the recovery process is operationalized and recovery outcomes are presented.

Above all, the justice theory originated from social psychology and has been used to demonstrate either psychological outcomes, such as satisfaction, loyalty, and trust, or behavioral outcomes, such as repurchase intention (Blodgett et al., 1997).

\subsection{Customer Satisfaction}

Customer satisfaction is a customer's overall attitude and impression of a service provider; it shows the emotional gap between what customers expect and what they receive (Zineldin, 2000). Service recovery procedures present an opportunity for service providers to improve customer satisfaction levels, and not surprisingly, the higher the recovery performance, the higher the post-recovery satisfaction, thus emphasizing the importance of superior service recovery (McCollough, Berry, \& Yadav, 2000). Once an organization attempts to recover from service failure, customers will reevaluate the service process (Tax, Brown, \& Chandrashekaran, 1998). According to Hart, Heskett, and Sasser (1990), the service recovery process has a positive influence on customer evaluation and behavior, and may actually strengthen the relationship between customers and organizations. Besides, effective service recovery may significantly influence customer loyalty, satisfaction, trust, and commitment (Hart et al., 1990; Smith \& Bolton, 2002; Tax \& Brown, 1998).

During service encounters, the distributive justice dimension refers to the perception outcome of fairness with respect to the service recovery process, for instance apologies or compensation to rectify actions (Patterson et al., 2006). When an individual perceives that benefits have not been allocated equitably, he/she experiences distress, which in turn motivates him/her to restore distributive justice. Studies have provided empirical evidence that perceived fairness of tangible outcomes has a positive effect on recovery evaluation (Boshoff, 1997; Goodwin \& Ross, 1992; Smith, Bolton, \& Wagner, 1999).

H1: The service recovery action of apology is positively related to distributive justice. 
Procedural justice focuses on the way some outcome is reached. It refers to the methods, including time or speed of the service recovery process, or adaptation to customers' recovery needs (del Río-Lanza et al., 2009). According to McColl-Kennedy and Sparks (2003), cognitive control has been found to have a direct, main effect on consumers' perception of procedural justice.

\section{H2: The service recovery action of cognition control is positively related to procedural justice.}

The service recovery context states that the interactional justice dimension helps evaluate the degree of customer experience with interactions between themselves and employees of service organizations during the recovery process (Sparks \& McColl-Kennedy, 2001). A previous study showed that the perception of interactional justice is directly related to the interpersonal treatment and communication of a firm's representatives during a recovery encounter (Prasongsukarn, 2005; Tax et al., 1998).

\section{H3: The service recovery action of formality is positively related to interactional justice.}

Service recovery encounters are processes triggered by service failure in the economic and social interactions between customers and hotels. Three dimensions of the justice theory that influence how individuals evaluate exchanges are distributive, procedural, and interactional justice. For overall customer satisfaction subsequent to service recovery actions, even one justice dimension may severely limit the potential for customer satisfaction (Tax \& Brown, 2000). Many research works have demonstrated that the justice theory significantly enhances overall customer satisfaction with service recovery (Mattila \& Patterson, 2004; McColl-Kennedy \& Sparks, 2003). Hence, it is expected that the three justice dimensions each considerably contribute to recovery evaluation and together explain a high percentage of variation in overall satisfaction with customer assessment of service recovery efforts (Patterson et al., 2006; Prasongsukarn, 2005). Failure to include the separate and complementary influence of perceived justice could lead to inappropriate conclusions and therefore, limit the explanatory power of the model.

Distributive justice focuses on the allocation of benefit and costs during the service recovery process. According to Tax \& Brown (2000), customers expect to be apologized and explained for their loss after service failure. Furthermore, distributive justice has been identified to impact customer satisfaction in many service industries (hotel, retail, airline, restaurant and bank) across some research methods.

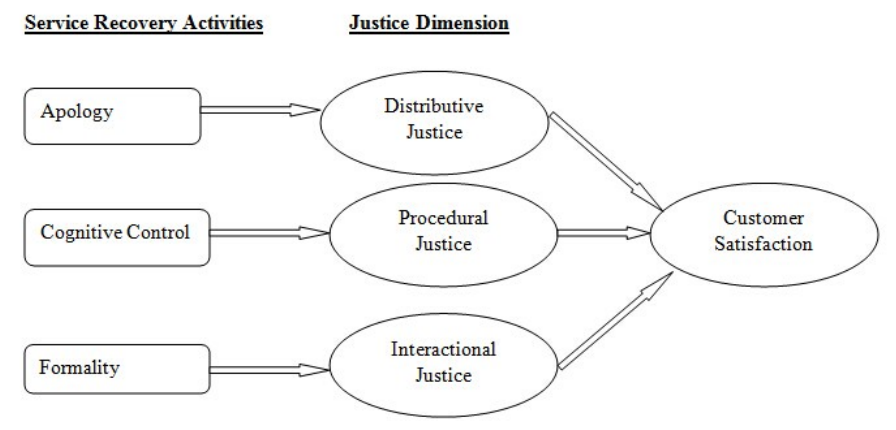

Figure 1. Proposed framework

H4: In a service recovery situation overall satisfaction with an organization's recovery efforts will be positively associated with perceptions of distributive justice.

Hoffman \& Kelly (2000) proved that even customers satisfied with service recovery strategy, the evaluation of recovery effort still maybe poor due to the process of service recovery. Moreover, several researchers have confirmed that customer satisfaction is not solely based on perceive distributive justice but also upon perceived procedural and interactional to achieve the final outcome (Tax \& Brown, 2000; Prasongsukarn, 2005; McColl-Kennedy \& Sparks, 2003).

H5: In a service recovery situation overall satisfaction with an organization's recovery efforts will be positively associated with perceptions of procedural justice.

The dominant theoretical perspectives on service recovery embrace both process and outcomes and are centered on the justice theory. The three dimensions of justice include distributive, procedural and interactional. Research involving the three justice concepts has been independently developed previously and has now been integrated into service evaluation in general and the service recovery context specifically. According to Hoffman \& Kelly 
(2000), interactional justice refers to how recovery outcome are presented, and suggested service recovery strategies did not impact satisfaction in a simple manner (McColl-Kennedy \& Sparks, 2003).

H6: After the service recovery process overall satisfaction with an organization's recovery efforts will be positively associated with perceptions of interactional justice.

\section{Method}

The researcher used the scenario approach as a combination of critical incident and complaints database. Nonetheless, the scenario approach has been criticized because the improvement of its internal validity is a tradeoff for its external validity, especially in the case of recovery situations where customers' emotions are more important than their cognition (Michel, 2001). A questionnaire was distributed for data collection and information gathering. Questionnaires are widely used because they are more reliable in terms of high return rate, less cost and more efficiency. This type of data collection also ensures a very high response rate.

\subsection{Measurement}

The questionnaire consists of four parts. Part A (service activities) was adapted from Prasongsukarn (2005), Karatepe (2006), and Boshoff, (1999); Part B with the justice theory scale was adapted from Smith et al. (1999); Part C (customer satisfaction) was adapted from Oliver and Swan (1989); and Part D contains background information. The seven-point Likert scale anchored with 1="strongly disagree" and 7="strongly agree" was used. Questions also addressed gender, age, and last experience with a hotel. Reliability reflects the reproducibility of a study when conducted at different times and places, and it is measured with Cronbach's Alpha. A Cronbach's Alpha value above 0.6 shows adequate instrument reliability, meaning that the data collected can produce results with high accuracy (Kumar \& Phrommathed, 2005). For the pilot survey, the Cronbach's Alpha values for the components ranged from 0.719 to 0.742 . No items were deleted and all Cronbach's Alpha values indicated the reliability of the measurement used in this study, and the instrument for this research had a high level of reliability.

\subsection{Sampling}

A total of 317 respondents were selected by stratified random sampling method from 1838 postgraduates of 12 disciplines at Anhui University of Science and Technology (AUST) China. The sample size for this study was determined using Cochran's formula (Cochran, 2007). After questionnaire distribution, 317 questionnaire sets were validly filled out and returned. All data collected from the respondents is analyzed in this chapter. To reach the sample size assumed previously and increase respondent rate, the researcher distributed 360 questionnaires to AUST, which is located in Anhui Province. A total of 350 questionnaires were collected out of 360 distributed, indicating a $97.2 \%$ return rate. Out of 350 returned questionnaires, 10 were incomplete and discarded, and 23 respondents were not qualified because they had a hotel experience more than 1 year ago. Having dropped cases of incomplete and disqualified questionnaires, exactly 317 questionnaires were used for data analysis.

\section{Analysis}

\subsection{Demographics Analysis}

Table 1. Demographics

\begin{tabular}{lll}
\hline & Frequency & Percent \\
\hline Gender & 157 & $49.5 \%$ \\
Male & 160 & $50.5 \%$ \\
Female & $\mathbf{3 1 7}$ & $100 \%$ \\
Total & & \\
Age & 85 & $26.8 \%$ \\
24 years old and below & 140 & $44.2 \%$ \\
$25-29$ years old & 36 & $11.4 \%$ \\
$30-34$ years old & 29 & $9.1 \%$ \\
$35-39$ years old & 12 & $3.8 \%$ \\
40-44 years old & 15 & $4.7 \%$ \\
45 years old and above & $\mathbf{3 1 7}$ & $100 \%$ \\
Total & & \\
Hotel experience & $\mathbf{3 1 7}$ & $100 \%$ \\
Under 1 year & & \\
\hline
\end{tabular}


Table 1 shows the gender, age and hotel experience of participants. It was found that females formed the majority of respondents in this survey (160/50.5\%) while only $157(49.5 \%)$ were male. The data analysis of this research was based on 317 usable questionnaires. Table 1 also shows the percentage and frequency of gender, signifying that $44.2 \%$ of respondents were between 24 and 29 years old. Those 24 years old and under comprised $26.8 \%$ and $4.7 \%$ were 45 years old and above. There were about $11.4 \%$ of respondents between 30 and 34 years old and about $9.1 \%$ and 3.8\% were between 35 and 39, and between 40 and 44 respectively. All respondents have checked in a hotel less than one year ago, so they were selected on purpose.

\subsection{Explanatory Factor Analysis and Reliability}

The statistical package for social sciences version 19.0 (SPSS 19) was used to conduct a principal component factor analysis with promax rotation and maximum likelihood estimation method. The initial EFA included all 32 questions proposed from 7 factors. The pattern matrix showing customer satisfaction of 1 was removed due to low factor loading. In addition, formality question 5, which loaded on apology, was also removed from the analysis. After revision, the final EFA included the remaining 30 variables that resulted in 9 factors with eigenvalues above 1.0 and that explained $65.218 \%$ of the total variance. In addition, factor loadings ranged from 0.559 to 0.985 , all of which were above 0.5 and loaded well on their factors. The pattern matrix identified 7 factors consistent with the primary constructs of interest and were further substantiated by the theory and related literature as expected. Furthermore, the KMO measure of sampling adequacy was 0.883 , which is higher than the recommended minimum of 0.6 (Kaiser, 1974). Table 4.3 shows Bartlett's Test of Sphericity, which was also found to be significant (Chi square $=9036.050, \mathrm{p}<0.001$ ). Bartlett's test of Sphericity is used to test the null hypothesis where the variables in the population correlation matrix are uncorrelated. The goodness-of-fit test shows non-significance, potentially due to the large data set.

The pattern matrix displays that each item highly loads on its own factor, although it also depends on the sample size. For a sample greater than 300 , anything above 0.3 is acceptable, although in the present study any loading below 0.5 or with an average below 0.7 was not accepted. It is evident from the pattern matrix that all individual item loadings are more than 0.5 and their average of one factor is more than 0.7. Since the loadings are high enough to be convergent and for discriminant validity, it was necessary to check whether there was any cross loading. From the pattern matrix it can be seen that there are no cross loadings. Additionally, for discriminate validity we will look into the factor correlation matrix and search for any loading greater than 0.7 . As show in Table 4.5 , there are no cross loadings above 0.7 , so it can be said that discriminant validity is achieved.

\subsection{Confirmatory Factor Analysis (CFA)}

Table 2. Goodness of fit indices for the proposed measurement model and modification measurement model

\begin{tabular}{llll}
\hline Goodness-of-fit Indices & Desirable range & Proposed Measurement model & Modification Measurement model \\
\hline $\mathrm{X}^{2}$ & Nil & 954.568 & 741.109 \\
CMIN/DF & $1-3$ & 1.711 & 1.343 \\
GFI & $\geq 0.80$ & 0.878 & 0.905 \\
AGFI & $\geq 0.80$ & 0.855 & 0.885 \\
RMSEA & $\leq 0.08$ & 0.043 & 0.030 \\
NFI & $\geq 0.80$ & 0.898 & 0.921 \\
CFI & $\geq 0.90$ & 0.955 & 0.978 \\
TLI & $\geq 0.90$ & 0.949 & 0.975 \\
\hline
\end{tabular}

Following EFA, a plausible model was identified. According to the pattern matrix from EFA, the proposed plausible measurement model was subjected to CFA, which was conducted to evaluate the model fit. Confirmatory factor analysis (CFA) should be conducted prior to the specification of an SEM model. CFA can also help verify the psychometric properties of the hypothesized measurement model and validity (Schmidt et al., 2006). According to Table 4.3, the Chi-Square, Goodness-of-Fit index (GFI), Adjusted Goodness-of-Fit index (AGFI), root mean square error of approximation (RMSEA) normed fit index (NFI), comparative fit index (CFI) and Tucker-Lewis index (TLI) were examined and reported as evidence of goodness-of-fit. Table 2 shows that after modification, all indicator variables loaded highly and significantly onto their respective factors. In addition, all the constructs were positively and significantly correlated with each other. In short, the initial model fit well. After modification, the model became more fit and better. The researcher also made a comparison of fit indices 
between the proposed measurement model and modified measurement model (see Table 2). The model improved and fit the data adequately. The CMIN was acceptable at 1.343, which was reduced from 1.711 (range of 1 to 3). The GFI and AGFI were all above the adequacy criterion and increased after modification. The RMSEA was adequate and reduced from 0.043 to 0.030 . The CFI, NFI and TCL were all acceptable and enhanced.

\subsection{Structural Equation Modelling (SEM)}

The final SEM resulted in goodness-of-fit indices appropriate for model interpretation with a non-significant Chi-Square and probability value greater than .05. The comparative fit index (CFI), Tucker-Leis Index (TLI), and standardized root mean square residual (SRMR) were used. The CFI and TLI had a cut-off value equal to or greater than 0.90 for an acceptable fit and equal to or greater than 0.95 for a good fit (Hu \& Bentler, 1999). SRMR of less than .05 indicated a good model, a root mean square error of approximation (RMSEA) less than .05 showed a good fit, or less than .08 showed acceptable fit (Kline, 2010). According to Table 3, $\chi^{2}=$ $67.412, \mathrm{p}<.001, \mathrm{CFI}=0.928, \mathrm{GFI}=0.954, \mathrm{TLI}=0.833, \mathrm{SRMR}=0.049, \mathrm{RMSEA}=0.131, \mathrm{PGFI}=0.307 . \mathrm{A}$ comparison between the initial and revised models is also presented. The majority of model-fit suggest an acceptable fit. The modification indices did not recommend any further means of improving the model. Several factors were considered before proceeding. The revised model is shown in Figure 2.

Table 3. Comparison of fit indices between initial model and revised model

\begin{tabular}{|c|c|c|c|c|c|c|c|c|}
\hline Index cut off & Chi-square & df & $\begin{array}{c}\text { GFI } \\
>.90\end{array}$ & $\begin{array}{r}\text { CFI } \\
>.90\end{array}$ & $\begin{array}{r}\text { TLI } \\
>.90\end{array}$ & $\begin{array}{l}\text { PGFI } \\
>.50\end{array}$ & $\begin{array}{l}\text { SRMR } \\
<.08\end{array}$ & $\begin{array}{l}\text { RMSEA } \\
<.08\end{array}$ \\
\hline Initial model & 281.316 & 12 & .828 & .670 & .422 & .355 & .067 & .243 \\
\hline Revise model & 67.412 & 9 & .954 & .928 & .833 & .307 & .049 & .131 \\
\hline
\end{tabular}

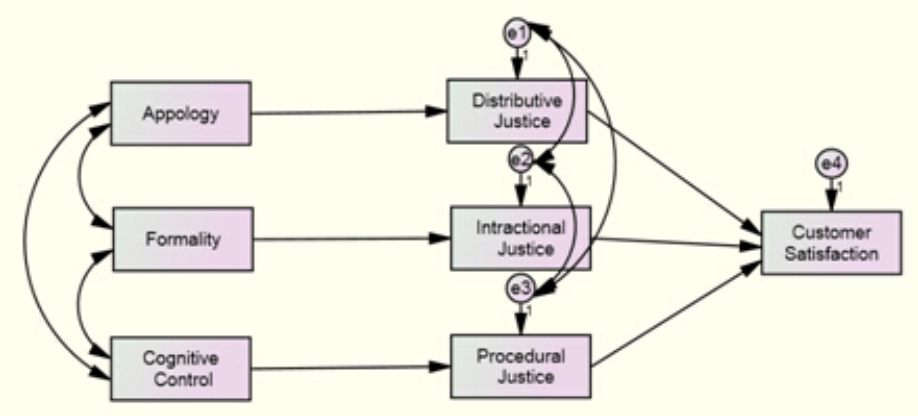

Figure 2. Revised model

\subsection{Correlation}

Table 4. Regression weights and correlations

\begin{tabular}{|c|c|c|c|c|c|c|c|}
\hline Hypothesis & Independent Variable & $\begin{array}{l}\text { Dependent } \\
\text { Variable }\end{array}$ & Estimate & SE & C.R & $\mathbf{P}$ & $\mathbf{R}$ \\
\hline H1 & Service Activities-Apology & Distributive Justice & .058 & .028 & 2.114 & .035 & .092 \\
\hline H2 & $\begin{array}{l}\text { Service Activities-Cognitive } \\
\text { Control }\end{array}$ & Procedural Justice & .073 & .026 & 2.777 & .005 & .115 \\
\hline H3 & Service Activities-Formality & $\begin{array}{l}\text { Interactional } \\
\text { Justice }\end{array}$ & .095 & .049 & 1.934 & .053 & .088 \\
\hline
\end{tabular}

Hypotheses 1, 2, and 3 regard the first research question whereby service activities are positively related to justice dimensions. The results of the hypothesis testing indicate that $\mathrm{H} 1$ and $\mathrm{H} 2$ are supported while $\mathrm{H} 3$ is weakly supported. Two are significant at the $p<.05$ level and one at $p=0.053$ that is close to the $p<.05$ level (see Table 4). The critical ratio (C.R.) for regression weight is calculated by dividing the regression weight by its standard error given. Table 4 shows the correlation between the independent and dependent variables. The 
estimate of correlation (r) between the service activities of apology and distributive justice is 0.092 and the critical ratio (C.R.) of covariance is 2.114 . The relationship between formality and perceived interactional justice is weakly significant (Estimate $=0.095, \mathrm{p}=.053$ ). This finding weakly supports H3.

\subsection{Mediation}

Bootstrapping is a re-sampling method employed to create a sampling distribution to estimate standard error and create confidence intervals. Bootstrapping can be used to confirm the mediation effect owing to its accuracy of computing confidence intervals for mediation effect when the mediation effect is non-zero. If the variables have measurement errors, the significance of the mediation effect is likely to be underestimated.

The hypotheses were related to the mediating effects of endogenous variables, namely justice dimension, service activities and customer satisfaction. The total effects of an independent variable on a dependent variable are the summation of direct and indirect effects. A direct effect is the effect of an independent variable on a dependent variable directly and without any mediator. On the other hand, an indirect effect is the effect of an independent variable on a dependent variable that is mediated by one or more intervening variables. According to Table 5, the interactional justice dimension has no mediating effect between formality and customer satisfaction, while distributive justice and procedural justice as mediators are supported.

Table 5. Mediation

\begin{tabular}{llll}
\hline Relationship & Direct without mediator & Direct with mediator & Indirect \\
\hline APPO DJUS CS & $0.07(0.203)$ & $-0.047(0.187)$ & Significant-Mediation \\
COGN PJUS CS & $0.156(0.007)$ & $0.076(0.04)$ & Significant-Mediation \\
FORM IJUS CS & $0.046(0.426)$ & $-0.075(0.043)$ & Not Significant-No Mediation \\
\hline
\end{tabular}

\section{Discussion}

Adequate service recovery strategies are important to hotels because of that service performances fail to meet customer expectations will always occur. The finding of this research revealed that there was a mediate effect of justice dimension among the service recovery actions and customer satisfaction china.

H1 -- The service recovery action of apology is positively related to distributive justice in China; H2 -- The service recovery action of cognition control is positively related to procedural justice in China; $\mathrm{H} 3$-- The service recovery action of formality is positively related to interactional justice in China. The SEM results provided evidence to support the direct relationships between service activities and perceived justice dimensions. The supported hypotheses confirmed the theoretical assumptions about the direct relationships and suggested that customer-perceived justice was affected by service actions and may further result in beneficial outcomes for hotels. H4 -- In a service recovery situation, overall satisfaction with an organization's recovery efforts will be positively associated with perceptions of distributive justice in China and it is supported; H5 -- In a service recovery situation, overall satisfaction with an organization's recovery efforts will be positively associated with perceptions of procedural justice in China and it is supported; H6 -- In a service recovery situation, overall satisfaction with an organization's recovery efforts will be positively associated with perceptions of interactional justice in China and it is rejected. This is because the customer must interact and communicate with the service provider and experience the organization's procedures for complaint resolution before any final outcome is determined. It was also found that the justice dimensions significantly affect customer recovery satisfaction because past research has invariably assumed that the three justice dimensions are activated simultaneously. However, H6 is not supported in terms of mediating effect. The reason may be that in H3, the relationship between formality and interactional justice was only weekly supported.

\section{Implication}

The study provides a useful insight into the behavior of potential hotel guests (students); they may be able to avoid experiencing service failure if offered proper subsequent follow-up service recovery activities by hotel. It also enlightens hotel manager to pursuing high level of customer satisfaction through perceive service recovery effort. In detail, hotel manager ought to develop specific monetary compensation guidelines while training employees especially receptionists to react various service failure situations accurately, including the apology skill. Furthermore, training programs should also concentrate on instilling suitable procedures and correct policies by reacting to customer problems swiftly and handling guest complaints in a timely manner. In addition, hotel managers should implement a training program that clearly illustrates exemplary reactions by teaching how to properly treat angry guests by demonstrating empathy and attentiveness. The findings allude to maximizing 
pleasing customers and for hotel managers to better develop procedures of service recovery. Thus, customer satisfaction may subsequently augment long-term customer relationships.

\section{References}

Adams, D. (1965). Pathogenesis of the Hyperthyroidism of Graves's Disease. British Medical Journal, 1(5441), 1015-1019. http://dx.doi.org/10.1136/bmj.1.5441.1015

Anderson, E. W., Claes, F., \& Mazvancheryl, S. K. (2004). Customer satisfaction and shareholder value. Journal of Marketing, 68(4), 172-185. http://dx.doi.org/10.1509/jmkg.68.4.172.42723

Bitner, M. J., Booms, B. H., \& Mary, S. T. (1990). The Service Encounter Diagnosing Favorable and Unfavorable Incidents. Journal of Marketing, 54, 71-84. http://dx.doi.org/10.2307/1252174

Blodgett, J. G., Hill, D. J., \& Tax, S. S. (1997). The effects of distributive, procedural, and interactional justice on postcomplaint behavior. Journal of Retailing, 73(2), 185-210. http://dx.doi.org/10.1016/S0022-4359(97) 90003-8

Boshoff, C. (1997). An experimental study of service recovery options. International Journal of service industry management, 8(2), 110-130. http://dx.doi.org/10.1108/09564239710166245

Boshoff, C., \& Leong, J. (1998). Empowerment, attribution and apologising as dimensions of service recovery: An experimental study. International Journal of Service Industry Management, 9(1), 24-47. http://dx.doi.org/10.1108/09564239810199932

Cochran, W. G. (2007). Sampling techniques. John Wiley \& Sons.

Davidow, M. (2003). Organizational responses to customer complaints: What works and what doesn't. Journal of Service Research, 5(3), 225-250. http://dx.doi.org/10.1177/1094670502238917

del Río-Lanza, A. B., Vázquez-Casielles, R., \& Díaz-Martín, A. M. (2009). Satisfaction with service recovery: Perceived justice and emotional responses. Journal of Business Research, 62(8), 775-781. http://dx.doi. org/10.1016/j.jbusres.2008.09.015

Fang, Z., Luo, X. M., \& Jiang, M. H. (2013). Quantifying the Dynamic Effects of Service Recovery on Customer Satisfaction Evidence From Chinese Mobile Phone Markets. Journal of Service Research, 16(3), 341-355. http://dx.doi.org/10.1177/1094670512445504

Goodwin, C., \& Ross, I. (1992). Consumer Response to Service Failure: Influence of Procedural and Interactional Fairness Perceptions. Journal of Business Research, 25, 149-163. http://dx.doi.org/10.1016 /0148-2963(92)90014-3

Gronroos, C. (1988). Service quality: The six criteria of good perceived service quality. Review of business, 9(3).

Hart, C. W. L., Heskett, J. L., \& Sasser, E. W. Jr. (1990). The Profitable Art of Service Recovery. Harvard Business Review, 68, 148-156.

Hoffman, D. K., \& Kelly, S. W. (2000). Perceived Justice Needs and Recovery Evaluation: A Contingency Approach. European Journal of Marketing, 34(3/4), 418-428. http://dx.doi.org/10.1108/030905600103 11939

Hu, L. T., \& Bentler, P. M. (1999). Cutoff criteria for fit indexes in covariance structure analysis: Conventional criteria versus new alternatives. Structural Equation Modeling, 6, 1-55. http://dx.doi.org/10.1080/107055 19909540118

Kaiser, H. F. (1974). An index of factorial simplicity. Psychometrika, 39(1), 31-36. http://dx.doi.org/10.1007/BF 02291575

Karatepe, O. M. (2006). Customer complaints and organizational responses: The effects of complaints's perceptions of justice on satisfaction and loyalty. International Journal of Hospitality Management, 25(1), 69-90. http://dx.doi.org/10.1016/j.ijhm.2004.12.008

Kau, A. K., \& Loh, E. W. Y. (2006). The effects of service recovery on consumer satisfaction: A comparison between complainants and non-complainants. Journal of Services Marketing, 20(2), 101-111. http://dx.doi. org $/ 10.1108 / 08876040610657039$

Kline, R. B. (2010). Principles and practice of structural equation modeling. Guilford press.

Kumar, S., \& Phrommathed, P. (2005). Research methodology. Springer.

Lee, M. J., Singh, N., \& Chan, E. S. W. (2011). Service failures and recovery actions in the hotel industry: A text-mining approach. Journal of Vacation Marketing, 17(3), 197-207. http://dx.doi.org/10.1177/13567667 11409182 
Mattila, A. S., \& Patterson, P. G. (2004). Service recovery and fairness perceptions in collectivist and individualist contexts. Journal of Service Research, 6(4), 336-346. http://dx.doi.org/10.1177/109467050 3262947

McColl-Kennedy, J. R., \& Sparks, B. A. (2003). Application of Fairness Theory to Service Failures and Service Recovery. Journal of Service Research, 5(3), 251-266. http://dx.doi.org/10.1177/1094670502238918

McCollough, M. A., Berry, L. L., \& Yadav, M. S. (2000). An empirical investigation of customer satisfaction after service failure and recovery. Journal of service research, 3(2), 121-137. http://dx.doi.org/10.1177/10 9467050032002

Michel, S. (2001). Analyzing service failures and recoveries: A process approach. International Journal of Service Industry Management, 12(1), 20-33. http://dx.doi.org/10.1108/09564230110382754

Miller, J. L., Craighead, C. W., \& Karwan, K. R. (2000). Service recovery: A framework and empirical investigation. Journal of operations Management, 18(4), 387-400. http://dx.doi.org/10.1016/S0272-6963(00) 00032-2

Nikbin, D., Ismail, I., Marimuthu, M., \& Jalalkamali, M. (2010). Perceived justice in service recovery and recovery satisfaction: The moderating role of corporate image. International Journal of Marketing Studies, 2(2), 47. http://dx.doi.org/10.5539/ijms.v2n2p47

Oliver, R. L., \& Swan, J. E. (1989). Equity and disconfirmation perceptions as influences on merchant and product satisfaction. Journal of consumer research, 372-383. http://dx.doi.org/10.1086/209223

Patterson, P. G., Cowley, E., \& Prasongsukarn, K. (2006). Service failure recovery: The moderating impact of individual-level cultural value orientation on perceptions of justice. International Journal of Research in Marketing, 23(3), 263-277. http://dx.doi.org/10.1016/j.jiresmar.2006.02.004

Prasongsukarn, K. (2005). The impact of cultural value orientation on customer perceptions of post-recovery service satisfaction in an Eastern context. University of New South Wales Sydney.

Schmidt, H., Heuer, F., Simon, U., Kettler, A., Rohlmann, A., Claes, L., \& Wilke, H. J. (2006). Application of a new calibration method for a three-dimensional finite element model of a human lumbar annulus fibrosus. Clinical Biomechanics, 21(4), 337-344. http://dx.doi.org/10.1016/j.clinbiomech.2005.12.001

Schoefer, K. (2010). Cultural moderation in the formation of recovery satisfaction judgments: A cognitive-affective perspective. Journal of Service Research, 13(1), 52-66. http://dx.doi.org/10.1177/10946 70509346728

Smith, A. K., \& Bolton, R. N. (2002). The effect of customers' emotional responses to service failures on their recovery effort evaluations and satisfaction judgments. Journal of the Academy of Marketing Science, 30(1), 5-23. http://dx.doi.org/10.1177/03079450094298

Smith, A. K., Bolton, R. N., \& Wagner, J. (1999). A model of customer satisfaction with service encounters involving failure and recovery. Journal of marketing research, 356-372. http://dx.doi.org/10.2307/3152082

Sparks, B. N., \& McColl-Kennedy, J. R. (2001). Justice Strategy Options for Increased Customer Satisfaction in a Services Recovery Setting. Journal of Business Research, 54(3), 209-218. http://dx.doi.org/10.1016/S0 148-2963(00)00120-X

Tax, S. S., \& Brown, S. W. (1998). Recovering and Learning From Service Failure. MIT Sloan Management Review, 40(1), 75-83.

Tax, S. S., \& Brown, S. W. (2000). Service Recovery: Research Insights and Practices. In T. Swartz, \& E. D. Iacobucci (Eds.), In handbook of Services Marketing and Management (pp. 271-286). Thousand Oaks, CA: Sage. http://dx.doi.org/10.4135/9781452231327.n19

Tax, S. S., Brown, S. W., \& Chandrashekaran, M. (1998). Customer evaluations of service complaint experiences: Implications for relationship marketing. The Journal of Marketing, 60-76. http://dx.doi.org/10.2307/1252 161

Zineldin, M. (2000). Total relationship management (TRM) and total quality management (TQM). Managerial Auditing Journal, 15(1/2), 20-28. http://dx.doi.org/10.1108/02686900010304399

\section{Copyrights}

Copyright for this article is retained by the author(s), with first publication rights granted to the journal.

This is an open-access article distributed under the terms and conditions of the Creative Commons Attribution license (http://creativecommons.org/licenses/by/3.0/). 